\title{
Analysis of Tuna Fish Resource Management (Thunnussp) on a Sustainable basis at Fish Landing in Bontotiro District Bulukumba
} Regency

\author{
Andi Eka Ratu ${ }^{1}$, Sudirman², Dewi Yanuarita ${ }^{2}$
}

\author{
${ }^{1}$ Student of Master Degree Fisheries Science, Faculty of Marine Science and Fisheries, Hasanuddin University, Perintis Kemerdekaan St. Km \\ 10, Makassar 90245, Indonesia \\ ${ }^{2}$ Department Of Fisheries, Faculty of Marine Science and Fisheries, Hasanuddin University PerintisKemerdekaan St. Km 10, Makassar 90245, \\ Indonesia \\ *e-mail: ekaratu80@yahoo.com
}

\begin{abstract}
This study aims to determine the management of the sustainability of tuna resources in Bulukumba Regency using the EAFM approach. This research was conducted in the waters of the Gulfof Bone by taking a fishing base location at the Fish Landing Port (PPI) of BontoTiro, Bulukumba Regency for four months, which began in December 2018 to March 2019. Analysis of data used in this study using 6 EAFM dimensions and assisted with Rapfish software.

The results of the study show that some dimensions have a fairly good sustainability value (> 50\%), namely on the social dimension (57.1\%), Habitat and ecosystem (57.25\%) and dimensions of fish resources (51.88\%). Tuna fishing activities that focus on the management of fisheries resources must be able to cover the regulation of fish resource use environmental management, and human activities in its management. In the smallest dimension in sustainable management, tuna is in the economic dimension with a value of $29.56 \%$ or in the bad category. This needs special attention from the local government of Bulukumba Regency, as well as at the provincial and central levels in raising the economic level offishing communities working on tuna fishing. There needs to be government policy and innovation in providing assistance and providing alternative new livelihoods and tuna processing which can have a significant impact on improving the welfare offishing.
\end{abstract}

Keyword-Management, Tuna Fish, Sustainable.

\section{INTRODUCTION}

Tuna commodity in 2017 based on the Ministry of Maritime Affairs and Fisheries in 2018 was able to produce an export value of 659.99 million US \$ with a total production volume of 198.131 tons. The amount is estimated to reach $16 \%$ of the total tuna production in the world. South Sulawesi region as one of the centers for producing fisheries in Indonesia. In 2018 the commodity of tuna, skipjack and cobs production amounted to 56,292, tons worth the US \$ 342,930 (Department of Marine and Fisheries of South Sulawesi Province, 2018).

South Sulawesi Province is one of the producers of tuna which is spread in Bone Bay and Makassar Strait. Sudirman, et al. (2018) explained the fishing base of tuna fishermen in Bone Bay in Bulukumba Regency, Sinjai Regency, Bone Regency, and Luwu Regency respectively. The increase in tuna activity that also occurs in Bulukumba Regency, from an economic point of view, is a profitable thing to continue but on the other hand, the activity will have an impact on the existence of tuna fish itself. In 2014, Bulukumba District showed an increasing trend in tuna fishing with total production reaching 241 tons, where the catch of tuna in the previous year was 221.3 tons (Department of Marine and Fisheries, Bulukumba Regency, 2014). Zainuddin, et al. (2015) explained that the level of utilization of tuna resource potential based on data from 2008-2013 showed that tuna catches on average were still below the allowed catch. Furthermore, Zainuddin, et al. 
(2015) described the amount of utilization of Total Allowed Catch (TAC) for tuna fish that has reached $55 \%$ in the waters of Flores sea

The activities of fisheries resource utilization activities especially on tuna fish by the fishermen who landed their catches at Bontotiro TPI experienced development or change. The fishing port that used to be a community fishing port is now managed by the Ministry of Maritime Affairs and Fisheries. The community that used to only market tuna in the nearest area now has an export scale. Exporters of tuna with an export scale provide distinct advantages for fishermen because of the tantalizing price certainty. But the fishing gear used still uses stretch fishing rods and works individually. So that for the increase in the number of catches, it must use labor/fishermen and fishing fleets whose numbers also increase.

Several studies have been carried out in analyzing the sustainable management of tuna in Indonesia, especially in waters in South Sulawesi (Bone and Sea of Flores), among others, by Sudirman, et al (2018) which have supply chains of tuna in South Sulawesi. Ma'arif (2011), Pranandi (2016) and Wiyono (2017) put more emphasis on capture technology aspects and the economic conditions of tuna fisheries in seeing the ability of sustainable management of tuna fis h in Indonesia. Research on the EAFM (Ecosystem Approach for Fisheries Management) approach has been carried out on tuna in Nusa Tenggara, and also on other fish species such as flying fish in the waters of the Makassar Strait and the Flores Sea. This study aims to determine the management of the sustainability of tuna resources in Bulukumba Regency using the EAFM approach.

\section{MATERIAL AND METHODS}

\subsection{Study Area}

Location and Time of Research This research was carried out in the waters of the Gulf of Bone by taking a fishing attribute base location at the Fish Landing Port (PPI) of BontoTiro, Bulukumba Regency for four months, which began in December 2018 to March 2019. The number of fleets currently operating is 79 , so the used in this study were as many as 22 units of tuna fishing vessels.

\subsection{Data Analysis}

a. Maximum Sustainable Yield (MSY) Analysis

$$
\frac{Y e}{f}=a-b f
$$

Where :

$$
\begin{aligned}
& \mathrm{a} \text { and } \mathrm{b}=\text { Constants } \\
& \begin{array}{ll}
\mathrm{Ye} & =\text { Catch (unit) } \\
\mathrm{F} & =\text { Arrest effort (unit) } \\
f_{\text {optimal }} & =\frac{a}{2 b} \\
M S Y & =\frac{a^{2}}{4 b}
\end{array}
\end{aligned}
$$

b. Sustainable Management Analys is

In this analysis using the ecosystem approach fisheries management (EAFM) approach was analyzed using raffish software. The general criteria for determining each dimension's attributes are the ease of being scored objectively, and the extreme point of sustainability can be stated simply as good or bad. The selected attribute must reflect the sustainability of each dimension and can be modified with other attributes if the information is available (Pitcher and Preikshot, 2001). The sustainability attributes of tuna management, both quantitative and qualitative, are grouped into six dimensions (fish resources, ecology, social, economic, technological, and institutional).

Table 1. Dimension attribute of EAFM

\begin{tabular}{|l|l|l|l|}
\hline No. & \multicolumn{1}{|c|}{ Dimension } & \multicolumn{1}{c|}{ Indicator } & \multicolumn{1}{c|}{ Methodology / Data collection } \\
\hline & & Raw CPUE & $\begin{array}{l}\text { Production of Tuna Fish in Bulukumba Regency } \\
2012-2017\end{array}$ \\
\cline { 3 - 4 } & $\begin{array}{l}\text { Fish Resource } \\
\text { Dimension }\end{array}$ & Fish Size Trend & $\begin{array}{l}\text { The size of tuna is landed at Bontotiro TPI in } \\
\text { Bulukumba Regency, through length measurements } \\
\text { and comparing length averages }\end{array}$ \\
\cline { 3 - 4 } & & $\begin{array}{l}\text { The proportion of tuna catches in 1 unit of tuna } \\
\text { fishing vessels }\end{array}$ \\
\hline
\end{tabular}




\begin{tabular}{|c|c|c|c|}
\hline & & Range Collapse & $\begin{array}{l}\text { The distance of the fleet in hunting down the catch } \\
\text { target }\end{array}$ \\
\hline 2 & Ecology Dimension & Water quality & $\begin{array}{l}\text { - } \text { Temperature } \\
\text { - chlorophyll }\end{array}$ \\
\hline \multirow{4}{*}{3} & \multirow{4}{*}{$\begin{array}{l}\text { Dimensions of } \\
\text { Fishing Technology }\end{array}$} & The selectivity of fishing gear & $\begin{array}{l}\text { Use of types of environmentally friendly fishing } \\
\text { gear }\end{array}$ \\
\hline & & $\begin{array}{l}\text { Fisheries capacities and arrest } \\
\text { efforts }\end{array}$ & $\begin{array}{l}\text { The number of fishermen's Effort who landed tuna } \\
\text { at TPI Bontotiro }\end{array}$ \\
\hline & & $\begin{array}{l}\text { Certification of fishing vessel crew } \\
\text { in accordance with regulations }\end{array}$ & $\begin{array}{l}\text { Personal data of fishermen and ships that land tuna } \\
\text { at TPI Bontotiro }\end{array}$ \\
\hline & & Size of the fishing vessel & $\begin{array}{l}\text { The shape and size of the fleet used in tuna fishing } \\
\text { activities }\end{array}$ \\
\hline \multirow{4}{*}{4} & \multirow{4}{*}{ Social Dimension } & Stakeholder participation & $\begin{array}{l}\text { Identification of stakeholders and fisheries } \\
\text { stakeholders in Bulukumba Regency }\end{array}$ \\
\hline & & $\begin{array}{l}\text { The working relationship of } \\
\text { fishermen }\end{array}$ & The working model of tuna fishing at PPI Bontotiro \\
\hline & & Stakeholder interaction & $\begin{array}{l}\text { Stakeholder activity in meeting activities to discuss } \\
\text { tuna management in Bulukumba Regency }\end{array}$ \\
\hline & & Fisheries Conflict & $\begin{array}{l}\text { Service activities, fishermen who land tuna at TPI } \\
\text { Bontotiro }\end{array}$ \\
\hline \multirow{4}{*}{5} & \multirow{4}{*}{ Economic Dimension } & Asset ownership & Number of productive assets of fishermen \\
\hline & & Working capital & Use of initial capital in tuna fishing activities \\
\hline & & Profit-sharing system & $\begin{array}{l}\text { The procedure for the distribution of income } \\
\text { between fishermen, bosses and collecting traders }\end{array}$ \\
\hline & & Household Income fishermen & $\begin{array}{l}\text { Income analysis of tuna production activities that } \\
\text { land tuna at TPI Bontotiro }\end{array}$ \\
\hline \multirow{4}{*}{6.} & \multirow{4}{*}{$\begin{array}{l}\text { institutional } \\
\text { dimension }\end{array}$} & $\begin{array}{l}\text { Compliance with the principles of } \\
\text { responsible fisheries }\end{array}$ & $\begin{array}{l}\text { Public perception of the use of environmentally } \\
\text { friendly fishing gear and the impact of fisheries } \\
\text { policy }\end{array}$ \\
\hline & & $\begin{array}{l}\text { Availability of facilities } \text { and } \\
\text { human resources in law } \\
\text { enforcement }\end{array}$ & $\begin{array}{l}\text { Availability of law enforcement activities in } \\
\text { monitoring tuna fishing activities in Bulukumba } \\
\text { Regency }\end{array}$ \\
\hline & & Management Plan & $\begin{array}{l}\text { Management plan designed by the Bulukumba } \\
\text { Regional Government in the preservation and } \\
\text { sustainability of tuna resources }\end{array}$ \\
\hline & & $\begin{array}{l}\text { Level of policy synergy and } \\
\text { fisheries management institutions }\end{array}$ & $\begin{array}{l}\text { Analysis of cooperation between fisheries } \\
\text { management institutions in Bulukumba Regency }\end{array}$ \\
\hline
\end{tabular}

\section{RESULTS AND DISCUSSION}

\subsection{Result}

The results In this study is the determination of sustainable management of tuna resources in Bulukumba Regency was based on six (6) dimensions used in the
EAFM standard consisting of (i) Fisheries Resources (ii) Ecology (iii) Fishing Technology (iv) Social (v) economy and (institutional). The following are the results of each dimension based on the results of the analysis using Rapfish software. 
a. Fish Resources Dimension

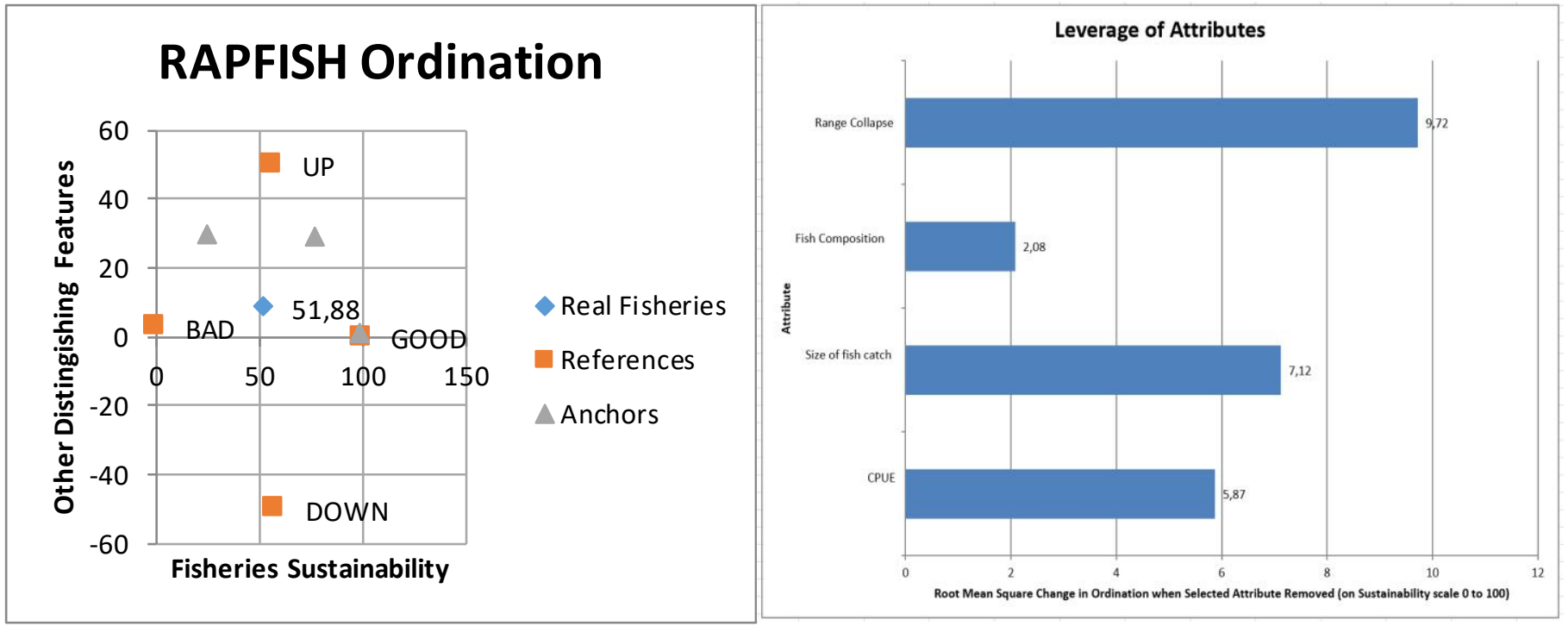

Fig.1: Results of Rapfish Analysis on Fish Resource dimensions

b. Ecology dimension
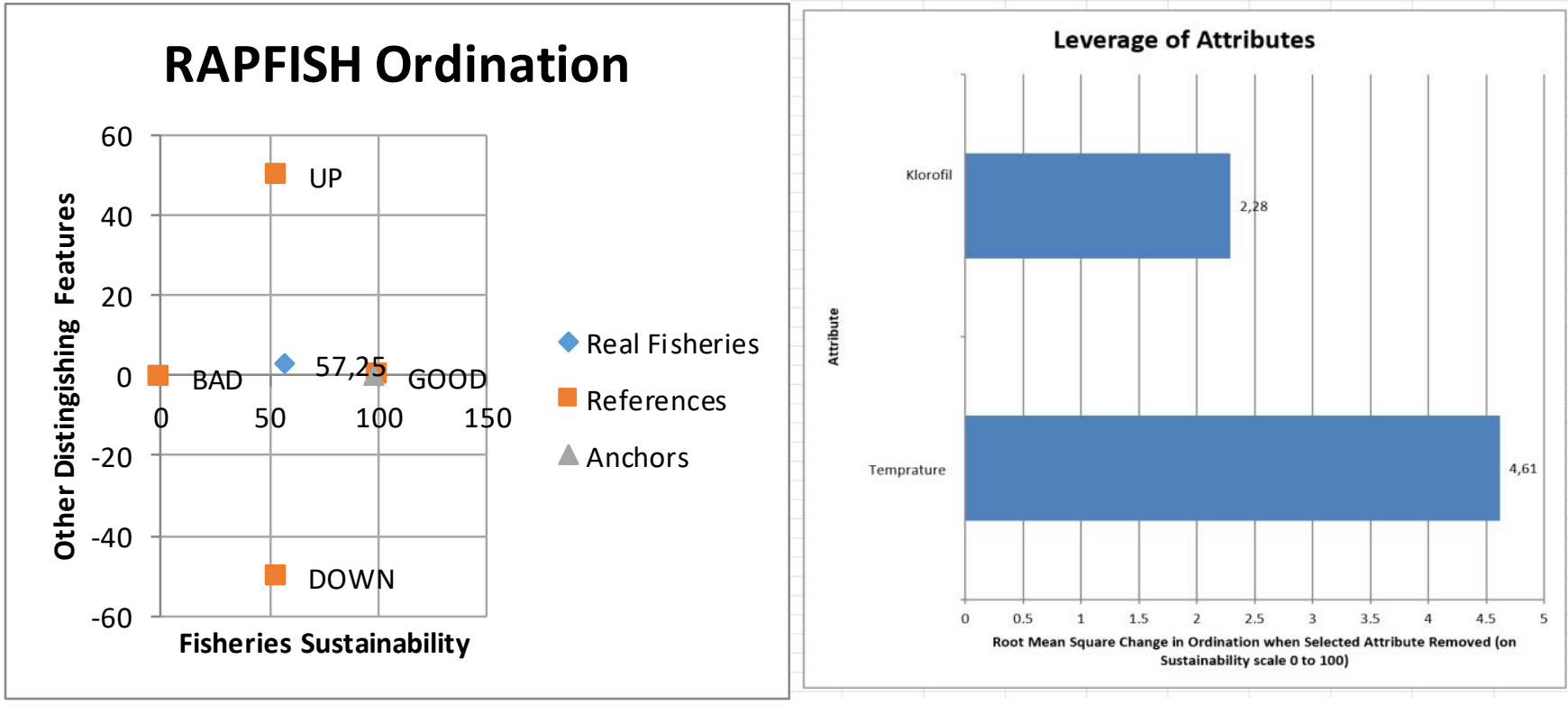

Fig.2: Results of Rapfish Analysis on the Ecosystem dimension 
c. Dimensions of Fishing Technology

RAPFISH Ordination
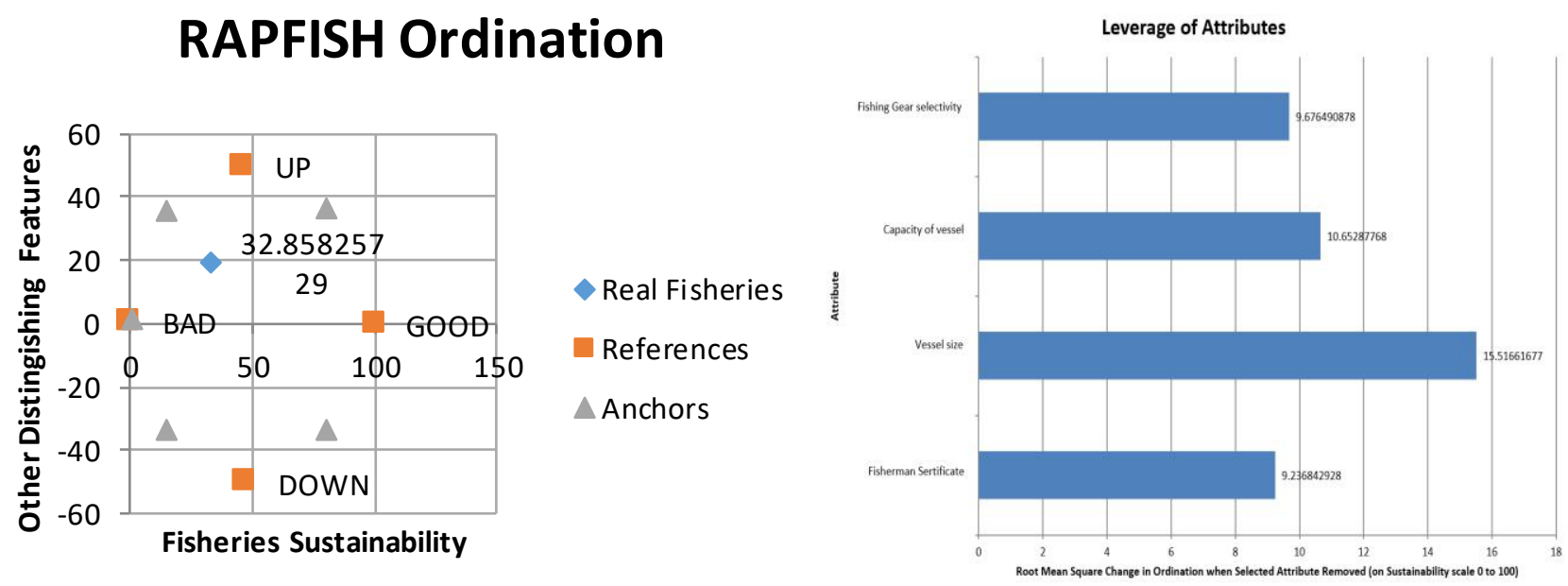

Fig.3: Results of Rapfish Analysis of the Fishing Technology dimension

d. Social dimension

\section{RAPFISH Ordination}

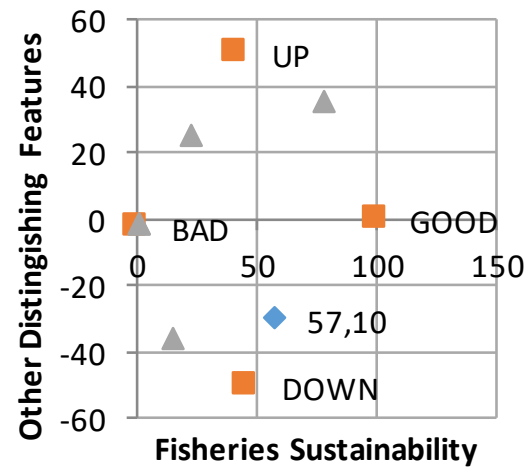

$\rightarrow$ Real Fisheries

References

$\triangle$ Anchors

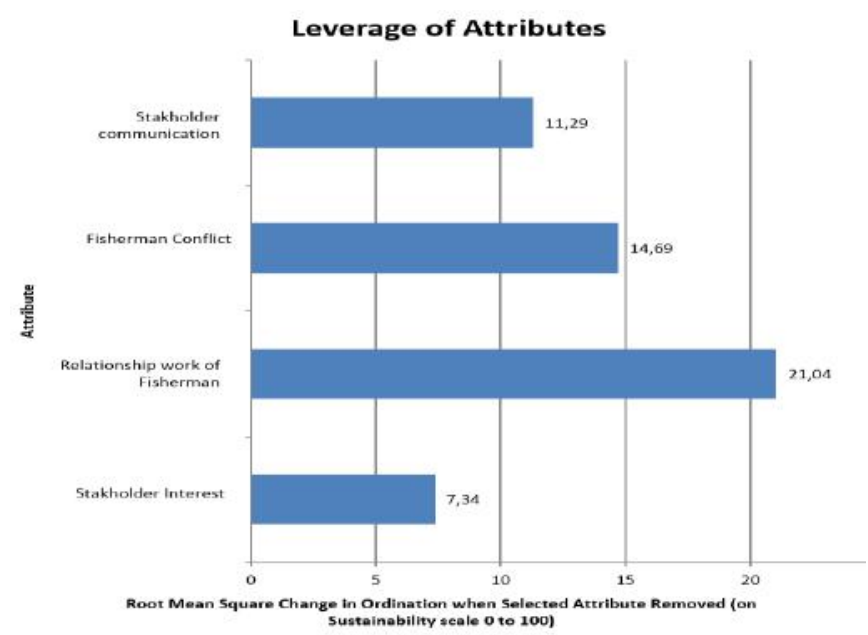

Fig.4: Results of Rapfish Analysis of Social dimensions

e. Economic dimension

\section{RAPFISH Ordination}

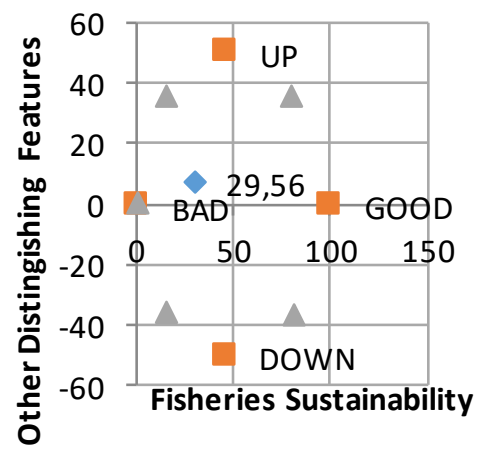

Leverage of Attributes

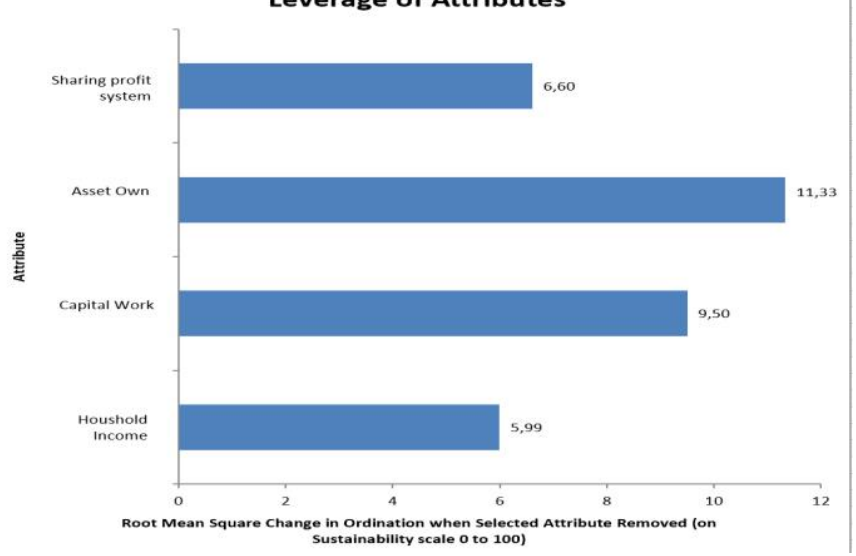

Fig.5: Results of Rapfish Analysis on the Economic Dimension 
f. Institution Dimension

\section{RAPFISH Ordination}
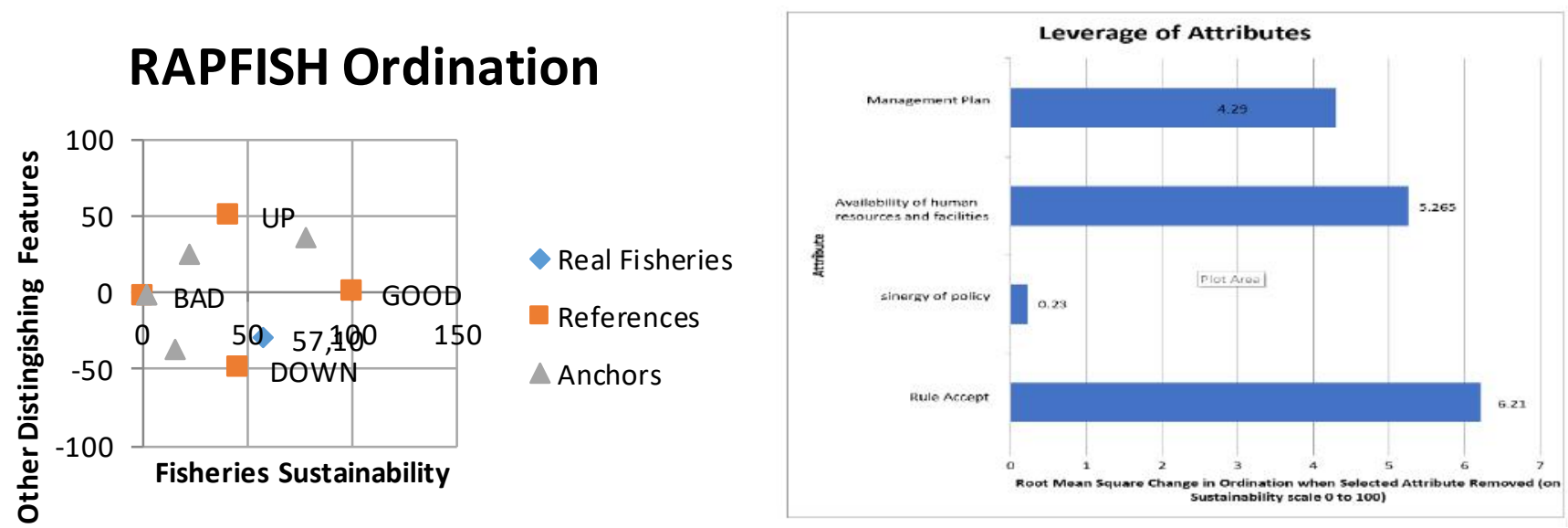

Fig.6: Results of Rapfish Analysis on Institutional Dimensions

\subsection{Discussion}

In the last 6 years, there have been developments in the number of fleets carrying out tuna loading and unloading activities at Bontotiro PPI so that this affects the optimum effort of catching tuna landed at PPI Bontotiro. Catch per unit effort is the annual fishery catch rate obtained using time series data for a minimum of five years. The following are CPUE results for tuna commodities landed in Bulukumba Regency during the period of 2012 to 2017 based on statistical data from South Sulawesi Province (table 2).

Table 2. CPUE of Tuna based on Production in Bulukumba Regency

\begin{tabular}{|c|c|c|c|}
\hline Years & Trip & Catch (ton) & CPUE \\
\hline 2012 & 1548 & 3309,9 & 2,138178 \\
\hline 2013 & 2016 & 1280,1 & 0,63497 \\
\hline 2014 & 2016 & 3309,9 & 1,641815 \\
\hline 2015 & 2052 & 9803 & 4,77729 \\
\hline 2016 & 2412 & 8897 & 3,68864 \\
\hline 2017 & 2520 & 2201 & 0,873413 \\
\hline
\end{tabular}

Source: Primary data after processing, 2019.

Based on the table and graph above shows the value of CPUE for tuna production in Bulukumba Regency experienced fluctuations in the last six years. The highest CPUE value was found in 2015 with a value of 4.77 tons/trip while the lowest value in 2013 was only 0.63 tons/trip. Based on the CPUE value that has been obtained and then continued using regression analysis, the regression equation is obtained as follows:

$$
\text { CPUE }=-6,777+0,004331 \mathrm{~F}
$$

In determining the sustainable products used in this study is to use the Schafer method approach. Based on the results of Schafer's analysis showed that the optimal CPUE value that can be done in 1 year is 782 trips while the amount of sustainable products that can be obtained in 1 year is 2650.1 tons.

Based on the results of the analysis of the dimensions of fish resources shows that the value dimension of fish resources in the management of tuna in Bulukumba Regency is at a value of 51.88 percent or in the good category. In the analysis of each attribute used in the assessment indicators of fish resource dimensions, attributes that have the highest sensitivity (leverage) are in attribute ranges collapse or tuna fishing distance. Based on the ecosystem dimension shows that the value of sustainability in the ecosystem and habitat dimensions is at a value of $57.25 \%$ which is in the good category. In the analysis of sensitivity attributes in ecosystem dimensions. The attributes of temperature and salinity are attributes that have the highest value or have a high enough sensitivity in the management of sustainable tuna in Bulukumba Regency. The conditions of temperature and salinity which have a significant change from time to time have a fairly high influence on the presence of tuna commodities in the catchment location which is the place for tuna fishermen production activities in Bulukumba Regency.

On the dimensions of fishing, technology is at a value of 32,86 or in the bad category. In the sensitivity analysis (leverages) on each of each attribute shows that the highest value is on the attributes of fishing vessel size modification or with a value of 15.52 . Modification of fishing vessel size as an attribute that has 
high sensitivity is caused because the fishing fleet used in tuna fishing activities is not in accordance with the condition of the correspondence possessed by the fishing fleet so that exploitation can occur in tuna fishing activities. the social dimension in tuna management is at the value of 57.10 percent or in good condition (good). On the other hand, the value of the raffish ordination analysis is still in the range of the down so that there needs to be an increase in the aspect of the social dimension. In analyzing each attribute used in this dimension, the attributes of the fishermen's work relationship have the highest sensitivity value with a value of 21.04. This indicates that the tuna fishing activities by Bulukumba fishermen who landed their fish in Bontotiro PPI by working in groups and are still traditional are the most important aspects that need to be considered in the sustainable management of tuna in Bulukumba

In the economic dimension that is at the value of 29.56 percent which describes the economic dimension in the bad category. From the results of attribute analysis which is a measurement on the economic dimension, the highest value on attribute sensitivity to be sustainable tuna management is found in the asset ownership attribute with a value of 11.33. Based on the table and the results of Rap Flying Fish analysis above shows that the value of institutional dimensions produces a sustainability index of 39, 1 percent or a poor sustainability index because it is below the 50 percent range. On each attribute that is used as a measuring instrument on the institutional dimension in the Leverages analysis (sensitivity) attributes indicate that the highest attribute is in compliance rules that is equal to 6.21. This shows that in tuna management in Bulukumba Regency, the attribute of regulatory compliance is the most important to be considered in tuna fishing activities. The fishing fleet used by tuna fishermen who landed at Bontotiro PPI is still difficult to be able to easily complete the letters as a condition for carrying out fishing activities in Indonesian waters

The management of fish resources in Bulukumba Regency, especially tuna, is a very important and prominent aspect in the fisheries sector as a determinant in the sustainability of production activities and tuna fishing. The following is an elevated diagram on each dimension used in tuna management in Bulukumba Regency in this study:

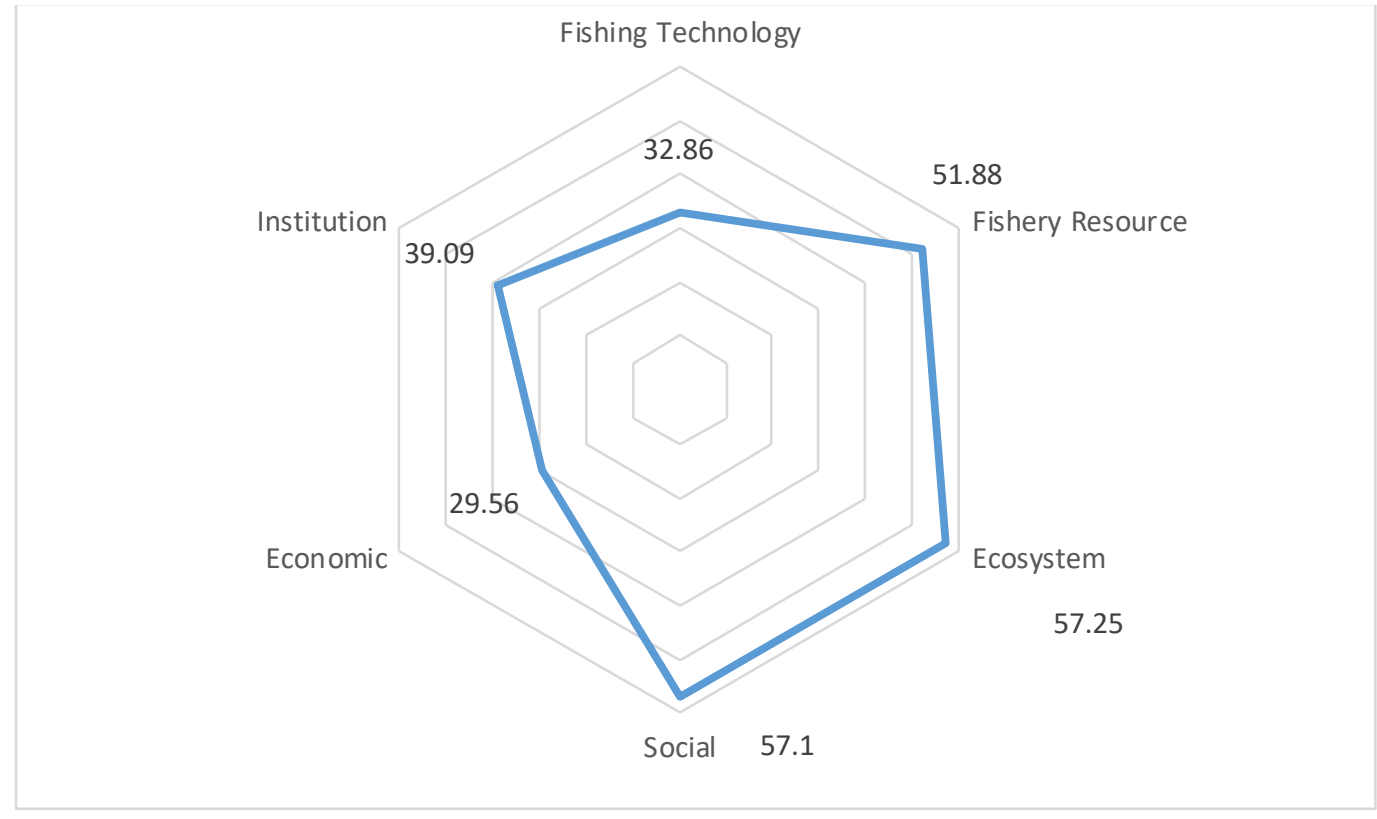

Fig.7: A Layout Diagram of the Overall Dimensions of EAFM in Tuna Management

Based on the elevated diagram above shows that some dimensions have fairly good sustainability value (> $50 \%$ ), namely on the social dimension (57.1\%), Habitat and ecosystem (57.25\%) and dimensions of fish resources
(51.88\%) Tuna fishing activities that focus on the management of fisheries resources must be able to cover the regulation of fish resource use, environmental management and human activities in its management. In the smallest 
dimension in sustainable management, tuna is in the economic dimension with a value of $29.56 \%$ or in the bad category. This needs special attention from the local government of Bulukumba Regency, as well as at the provincial and central levels in raising the economic level of fishing communities working on tuna fishing. There needs to be government policy and innovation in providing assistance and providing alternative new livelihoods and tuna processing which can have a significant impact on improving the welfare of fishing communities in Bulukumba Regency.

\section{CONCLUSION}

Based on an analysis of the sustainability of tuna resources in Bulukumba with the raffish method, the dimensions of habitat and ecosystems, the social dimension, the dimensions of fish resources management can continue. While the institutional dimensions, dimensions of fishing technology and the economic dimensions of management cannot continue.

With the description of CPUE value, social conditions and ecosystem conditions in tuna activity in Bulukumba Regency, it can be a recommendation for rules and policies to provide limits on fishing activities to maintain tuna resources in Bulukumba Regency.

\section{REFERENCES}

[1] Adi Jufri, M. Anshar Amran, and Mukti Zainuddin, 2014. Characteristics of Areas of Catching Cakalang in West Season on the Waters of the Bone Bay. Fisheries Department, Raja Ali Haji Maritime University, Riau Islands, Marine Science Study Program, FIKP, Hasanuddin University.

[2] Adrianto L. 2005. Implementation of the code of conduct for responsible fisheries in the perspective of developing countries. Working paper, 29 March 2005. Center for IPB Coastal and Ocean Resources Studies (PKSPL). Bogor. 15 p.

[3] Agustini, Fauziah. 2011. Advanced Human Resource Management. Medan:

[4] Alder J .et.al. 2000. How Good is Good? A Rapid Appraisal Techniques for Evaluation of The Sustainability Status of Fisheries of The North Atlantic. In Paul and Pitcher (eds). Methods for Evaluation The Impact of Fisheries on The North Atlantic Ecosystem. Fisheries Center Research Report,200 Vol (8) No.2. Pitcher dan Preikshot, 2001

[5] Atuna. 2018. Tuna Fishing Statistics.http://www.atuna.com.

[6] Bappenas, 2014. Report on the Achievement of the Millennium Development Goals in Indonesia 2014. Jakarta: National Development Planning Agency (BAPPENAS)
[7] Barut, C, Noel dan Elaine G. 2016. Philippine Annual Fishery Report. Scientific Committee Twelfth Regular Session. Bali, Indonesia 3-11 August 2016

[8] Central Statistics Agency, 2017. Central Table Statistics Agency. Taken back from the Central Bureau of Statistics: https://www.bps.go.id/site/resultTab

[9] Charles AT. 2001. Sustainable Fishery Systems. United Kingdom: Blackwell Science Ltd. 370 p.

[10] Charles, A.T. 2002. Sustainable Fishery System. Blackwell Science.UK

[11] Dahuri, Rokhmin (2003). Marine Biodiversity - Indonesia's Sustainable Development Assets.

[12] Department of Marine and Fisheries, Bulukumba Regency, 2018. Annual Report on the Production of Catches for the 2008-2018 Period. Bulukumba (ID): DKP.

[13] Dinah. 2008. Introduction to Capture Fisheries. Bogor: Department of Fisheries Resource Utilization, Faculty of Fisheries and Marine Sciences, Bogor Agricultural Institute. 60 pages.

[14] Faizah, 2010. Bioeconomic Analysis and Profit Sharing System for Big Eye tuna fisheries (Thunnusobesus) in the Gulf of Pelabuhanratu, West Java.

[15] FAO, CCRF. 2000. Code of Conduct for Responsible Fisheries. Rome.

[16] Fauzi A and S Anna. 2002. Evaluation of Fisheries Development Sustainability Status: Application of Rapfish Approach (Case Study of DKI Jakarta Coastal Waters). Indonesian Coastal and Ocean Journal Vil 4 (2) pp: 36-49.

[17] Fauzi A and S Anna. 2005. Fisheries and Marine Resource Modeling for Policy Analysis. Jakarta. PT Gramedia Main Library. 343 pages.

[18] Garcia SM., and Cochrane KL. 2005. Ecosy stem approach to fisheries: a review of implementation guidelines. ICES Journal of Marine Science, 62: 311- 318

[19] Hadikusumah et all, 2005. Variability of Temperature and Salinity in Cisadane Waters. Makara, Science. 12 (2): 82-88.

[20] Hengky W. Pramana, (2006), Access 2003 based Inventory Application, Elex Media Komputindo, Jakarta.

[21] Jamal, M., M.F.A. Condit, J. Haluan, and B. Wiryawan. 2011. Utilization of Cakalang Fish Biology Data (Katsuwonuspelamis) in the Framework of Responsible Fisheries Management in the Waters of Bone Bay. Indonesian Natur Journal

[22] Law No. 45 of 2009 concerning Amendment to Law No. 31 of 2004 concerning Fisheries.

[23] Lirdwitay aprasit, et al. 2017.Thailand National Report to the Scientific Committee of the Indian Ocean Tuna Commission 2017. Indian Ocean Tuna Commission.

[24] Marine and Fisheries Agency, 2017. South Sulawesi Province Fisheries Statistics Report. Ministry of Marine Affairs and Fisheries.

[25] Ministry of Maritime Affairs and Fisheries, JICA. 2011. Indonesian Fisheries Book 2011, KKP and JICA, Jakarta. 
[26] Ma'arifRoisul. 2011. Evaluation of Tonda Fishing in Pacitan Fishing Activities Against Tuna Resource Conservation. Bogor Agricultural Institute. Tesis

[27] Paulette, R.T and A.A. Widodo. 2010. Size of midnight fish (Thunnusalbacares) captured using hand lines in Maluku waters. National Symposium on the Development of the Marine Sector in Eastern Indonesia. Center for Marine and Fisheries Socio-Economic Research, Jakarta.

[28] Mallawa, A., Musbir, F. Amir, and A.A. Marimba. 2012. Analysis of the Size Structure of Cakalang (Katsuwonuspelamis) According to Season, Region and Technology of Fishing in Luwu Waters Bone Bay, South Sulawesi. J. Science and Technology of Behind Faith Vol.3 No.2: 29-38.

[29] Nikijuluw, V.P.H. 2002. Fisheries Resource Management Regime PT. Cidesindo Library. Jakarta.

[30] Ningsih O, WL Sisera, Pesulima W, Kirk JW, Ginzel FI. 2015. Preliminary Study of Reproductions of Yellow Fin Tuna Caught in Waters of East Nusa Tenggara. Inside: WWF Indonesia, editor. National Symposium on Management of Sustainable Tuna Fisheries; 2014 Dec 1011; Bali, Indonesia. Jakarta (ID): WWF Indonesia. pp. I-117 - I-122

[31] Pitcher TJ. and DB Preikshot. 2001. Rapfish: A Rapid Appraisal Technique to Evaluate The Sustainability Status of Fisheries. Fisheries Research 49(3):255-270.

[32] Pranadi, Gilang Aditya. 2016. Prospects for the Implementation of Traceability of Tuna and Cakalang Fisheries at the Coastal Fisheries Port (PPP) in Sadeng, GunungKidul, Yogyakarta. Bogor Agricultural Institute. Tesis

[33] Rice JC, Rochet MJ. 2005. A framework for selecting a suite of indicators for fisheries management. ICES J. of $\mathrm{Mar} \mathrm{Sc}$ 62:516-527

[34] South Sulawesi Province in Figures, 2018. South Sulawesi Central Bureau of Statistics.https://sulsel.bps.go.id/publication/2017/08/11/455 3db6f70f3678ad383d1b9/provinsi-sulawesi-selatan-dalamangka-2017.html

[35] Statistics of the Department of Marine and Fisheries (2012). South Sulawesi in numbers. South Sulawesi.

[36] Sumadhiharga k, 2009. Tuna. Oceanographic Research Center of the Indonesian Institute of Sciences

[37] Syarief, R. and HaryadiHalid. 2010. Food Storage Technology. Arcan Publisher, Jakarta.

[38] Usman. 2006. Social Research Methods. Earth Literacy. Jakarta.

[39] Widodo, J and S. Nurhakim. 2001. Concept of Fisheries Resource Management. Presented in Training of Trainers on Fisheries Resource Management. Clarion Golden Hotel. Jakarta. October 28 to November 2, 2002.

[40] Zainuddin, Mukti, et al. 2015. Estimation of Potential and Mapping Potential Zones of Tuna Catching in the Flores
Sea: Remote sensing and geographic information systems. Indonesian Ikhtiologi Journal 15 (2): 129-141. 